\title{
Approach of Electronic Government to Closing the Gap between Public and Citizens
}

\author{
Krish Rugchatjaroen \\ Mahidol University, Thailand \\ krish.rug@mahidol.ac.th
}

\begin{abstract}
Electronic government uses ICT to improve public activities, bringing also greater organizational efficiency and effectiveness. The aim of this research is to study electronic government in Thailand to move towards success. The questionnaire obtained information on the current status of electronic government in Thailand which intendeds to investigate factors relating to information technology by interviewing state employees in National Electronics and Computer Technology Center: NECTEC. The results reveal 6 conclusion based upon the following area of study; 1) Investment: budget allocations for the integration of ICT in the public sector by considering the national strategic plan and the ASEAN community strategies, to increase the competitiveness and investigate in infrastructure and logistics. 2) Officials' knowledge and understanding: involving the full cooperation from government agencies workshops on the development of information systems for public sector officials to allow implementation of the projects to restructure more efficiently the form of electronic government. 3) Citizens' understanding: which investigated the public sectors acceptance of public participation and people-centered government services? There are wide gaps between those used in municipal and non-municipal area. 4) Networking: the form of networking through a collaborative network of TOT and CAT in the core layer, which makes the network redundancy and high availability. 5) Promoting: using website to promote activities and disseminate knowledge about technology in electronics and computer project or training. and 6) Policies: the manner the Ministry of Information and Communication Technology, allocates resources in their expansion of telecommunications infrastructure and communication channels and the way they encourage full access to ICT that will lead to close the gap.
\end{abstract}

Keywords: Electronic government, public service, NECTEC

\section{Introduction}

Electronic government has become a natural extension of the information technology revolution that has accompanied the Knowledge Society. E-government means adding good governance into an evaluation of government performance, (Mohammad, 2008) by using Information and Communication Technologies (ICTs) to improve public activities, bringing also a promise of greater organizational efficiency and effectiveness. The projects are being implemented in developing and transitional economics and societies. Economics and social change nowadays, many countries adapted to keep pace with economic and social changes that occur, it will require the use of information technology because of advanced information society continues and is likely to be even more. Technology has a role in daily life, people themselves are struggling to adapt coping with rapid social and economic changes that information technology has evolved rapidly as well as organization in this era of government and private organizations. Information technology has brought many benefits to the management of the organization. The technology cannot be used efficiently if lack of information technology, information management, good control system, such as data transmission (Ott et al., 1990).

Current government has taken to improve the management of information technology to replace some of working process. The state has determined that information technology can help government agencies reduced the problem and made responsive needs' of citizens. There is some reason of these beliefs; technology is processing information quickly which is much faster than human. The tasks in coordination with the various agencies that play a role in technology are helping accelerate the coordination of the organizations as well. It is said that IT can help provide a batter "Organizational Memory" and manage the organization to complete form with rules and accountability (Rosenbloom \& Kravchuk, 2005). Therefore, this research aimed to study the electronic government in Thailand to move towards success. By using research's questions, what is the current situation of the government? What are the issues of flexibility electronic government? Is the government agency ready to step into the electronic state? What are the gaps between government and citizens in using electronics? The findings will be useful and effective in the management of public service organizations, government will have to plan and construct 
improvements to the state organizations for quick public services. However electronic government reduced cost and increasing the transparency of organizations. Finally results can be guidelines for powered electronic state in the country to move towards success and built economic development and political stability of the country.

\section{Electronic Government}

A. Scope of electronic government: Since the 1990s, the Public Sectors of Western countries have developed "electronic government: eGovernment" mostly means ePublic administration by using information and communication technology (ICT) by the way ICT has developing in technical for serving public service in Public Administration field therefore the citizens ongoing in discussions of e-Government also called "eGov". A variety of projects in the public services have been used information technology. Are they called eGov project? What is the scope of eGov? Bannister (2010) said in "A Handbook of eGovernment Information, Technology, and Transformation" written in Hans J. Scholl, has conclusion about scope of eGovernment focusing on good majority, like to distinguish eGovernment from what? And when? by defining eGovernment as technology which is usually meant the internet system and website that enables governments to interact directly with citizens and distinction may be valid, but it is not particularly for citizen and interpretation with eGov by using "The Public Sector: An Onion-Shaped Model" for the first thing on public administration field should be sprit and create the layer for management because the public sector may be considered and analyzed as a series of layers where distance from the center is inversely proportional to the degree of day-to-day political control managed by the government and the central public administration. The model has shown that government and public administration managing from center that will be creating an administrative core. This is often referred to as the "civil services." The Central Administrative Core must be created by democratic. It is commonly referred to as the central or federal government civil service by advising and assisting in the formulation of government policy then deploy form core center like a Central Administrative Core going to State Agencies, Local Government, Wider Public Sector and Commercial State Sector like an onionshaped model (see fig 1.) therefore the Commercial State Sector on the outer rim of the model. Even though stat involvement in industry has been declining for several decades, governments still own or run a remarkable range of commercial enterprises (Bannister, 2010).

Figure 1: Model of central government and public administration management

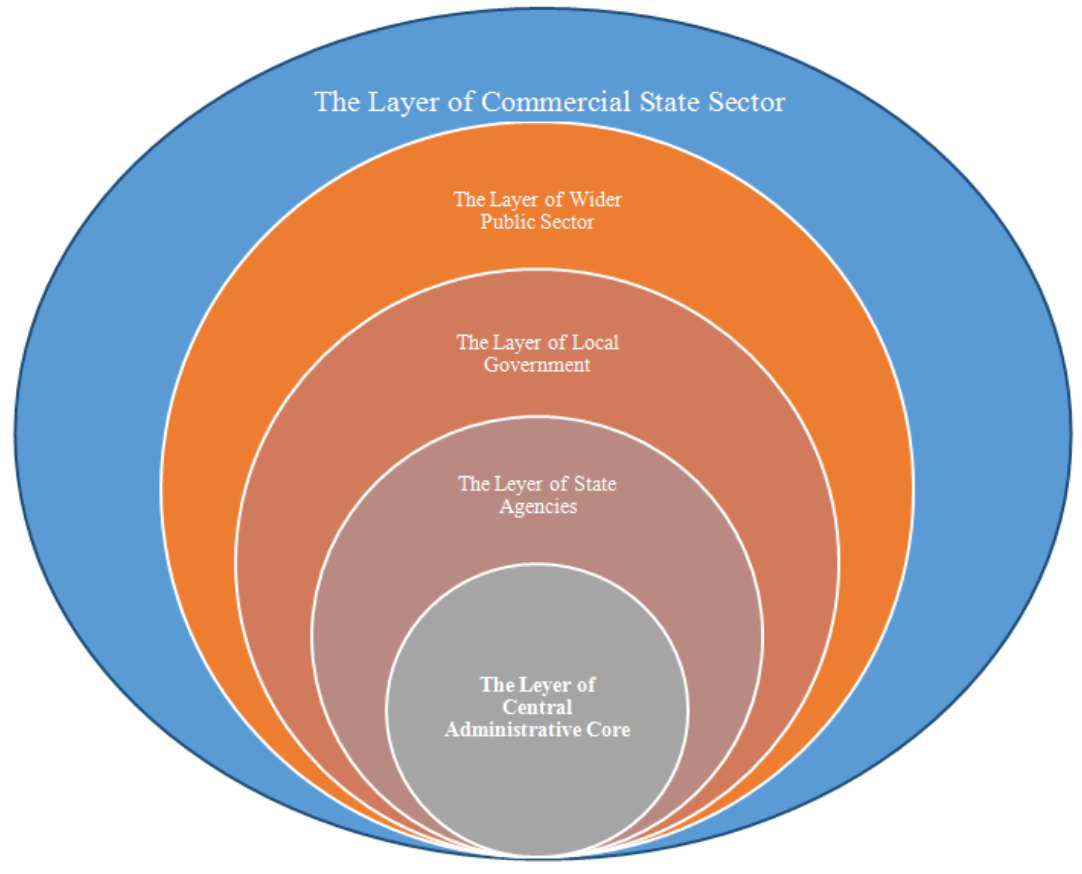

B. Classification of electronic government: Bannister given classified electronic government into 6 aspects as follow; (see fig 2.) all of classifies are provide for public services in information and communication technology under the slightly alarming heading "eGov". 


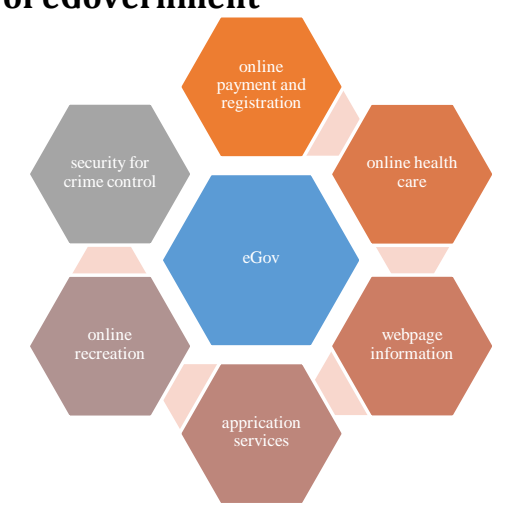

C. From government to eGovernment: A research result by Klischewski founded the website service technologies decrease transaction costs of eGovernment related interaction, therefore all actors involved will be reconsider their roles and value propositions. These propositions have been developed in the areas of information management, creation of service value, and leadership in administration, based on identifying technology induced challenges as well as new opportunities leading to new role conception in administrations (Klischewski, 2010). In the pass, citizen attitude in the government based on monopoly, sole caretaker and bureaucracy styles. This is an importance thing to improve the old styles for changing in good public services to citizen. eGovernment have challenge and opportunity for clear the problem with old style then many profit from eGov. Such as; create information dissemination to consumption from citizens/businesses, specified value creation in a network of electronic service providers, and setting standards for technical, semantic, organizational, legal, social "interoperability". See conclusion in table 1.

Table 1: The Arrangement of Channels

\begin{tabular}{|c|c|c|c|}
\hline From Government as & Info monopolist & Sole caretaker & Bureaucratic leader \\
\hline $\begin{array}{l}\text { Challenges "anomalies" based } \\
\text { on website technologies and } \\
\text { methods }\end{array}$ & $\begin{array}{l}\text { Relevant information } \\
\text { provided / managed / } \\
\text { owned by many, often out } \\
\text { of administration control }\end{array}$ & $\begin{array}{l}\text { "competitors" offer } \\
\text { (value-added) } \\
\text { administration } \\
\text { services }\end{array}$ & $\begin{array}{lr}\text { Empowerment } & \text { of } \\
\text { citizens } & \text { and } \\
\text { administration } & \\
\text { employees } & \end{array}$ \\
\hline $\begin{array}{l}\text { Opportunities based } \\
\text { website technologies and } \\
\text { methods }\end{array}$ & $\begin{array}{l}\text { Information } \\
\text { dissemination to and } \\
\text { consumption from } \\
\text { citizens / businesses }\end{array}$ & $\begin{array}{lr}\text { Specific } & \text { value } \\
\text { creation } & \text { in } \begin{array}{r}\text { a } \\
\text { network }\end{array} \\
\text { efectronic } & \text { service } \\
\text { eleviders } & \end{array}$ & $\begin{array}{l}\text { Setting standards for } \\
\text { technical, semantic, } \\
\text { organizational, legal, } \\
\text { social } \\
\text { "interoperability" }\end{array}$ \\
\hline To Government as & $\begin{array}{l}\text { Information provider, } \\
\text { broker, and consumer }\end{array}$ & $\begin{array}{ll}\text { Service } & \text { provider } \\
\text { and } & \text { network } \\
\text { manager } & \end{array}$ & $\begin{array}{l}\text { Facilitator and } \\
\text { framework provider }\end{array}$ \\
\hline
\end{tabular}

Source: R. Klischewski (2010) [5]

D. Focusing dimensions: Survey of "Agriculture Market Information Services (AMIS) in the Least Developed Countries (LDCs): Nature, Scopes, and Challenges." Isalam \& Grönlund (2010) concluded information system project evaluation matrix for evaluate and studies impact of quantify some benefits of the projects. 5 dimensions were conducted; Users: who are the targeted? what do they need? when do they get the services? how do they access the services? Management: who is the manager? what are the roles of participants? when did it start and end? How are the targeted needs? Funding: who provides the funds? what is the functional of funding? what was the period of funding? how to managed fund?

Infrastructure: who provides supply and demand sides' infrastructure? what infrastructures are considered on supply and demand sides? when does the infrastructure readily available? how the infrastructure is used? Data: who are the actors? what are the data? when is the dada processed? how is the data processed? (see fig 3.) 
Figure 3: Information system project evaluation

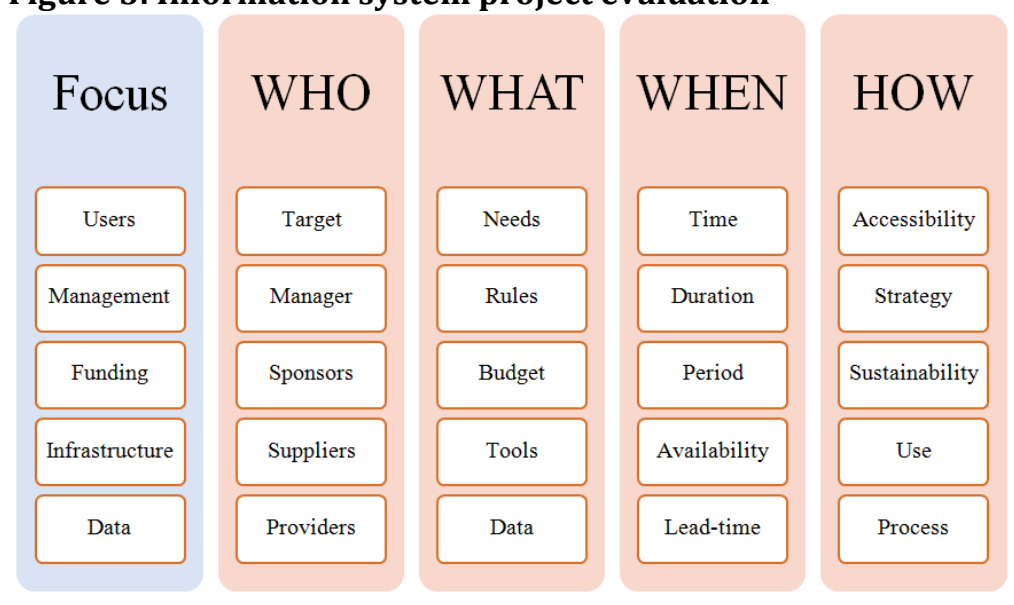

The concept of eGovernment questions are providing for interpretation how to prepare the eGovernment project and improve worst eGovernment project depend on 5 dimensions included User, Management, Funding, Infrastructure, and Data by using New Public Management concept. (Yee et al., 2005), which of the following can be classified as eGovernment management: 1) Openness: The online system can advertise its policies and practices related to the management of personal information as well as provided easily accessible links to his information. 2) Limiting collection: The online system limits the collection of information which is necessary for the purposes identified and ensures, the collection will be done by fair and lawful. In addition, the online system keeps secure logs of its data collection that complied with this principle if challenged. 3) Safeguards: Security safeguards such as authentication and encryption can be implemented. 4) Challenging compliance: The online system can provide a facility for the individual to address a compliance challenge to someone who has been identified as accountability. 5) Consent: The person's consent is obtained by the online system in form of a signed certificate to guarantee authentication and non-repudiation. 6) Identifying purpose: The purpose is clearly identified by the online system and can be retrieved. 7) Limiting use, disclosure and retention: The online system keeps secure logs of its uses, disclosures, or retention of data so that it can prove that it has complied with this principle if challenged. 8) Accountability: Contact information of the person who is accountable can be clearly advertised in the online system. 9) Accuracy: First, ask the individual providing the data to verify data and sign off on its accuracy and completeness. Second, periodically request the individual to update personal information. Finally, run rule-based checks on the data to identify inconsistencies. (see fig 4.)

Figure 4: Classified as eGovernment management

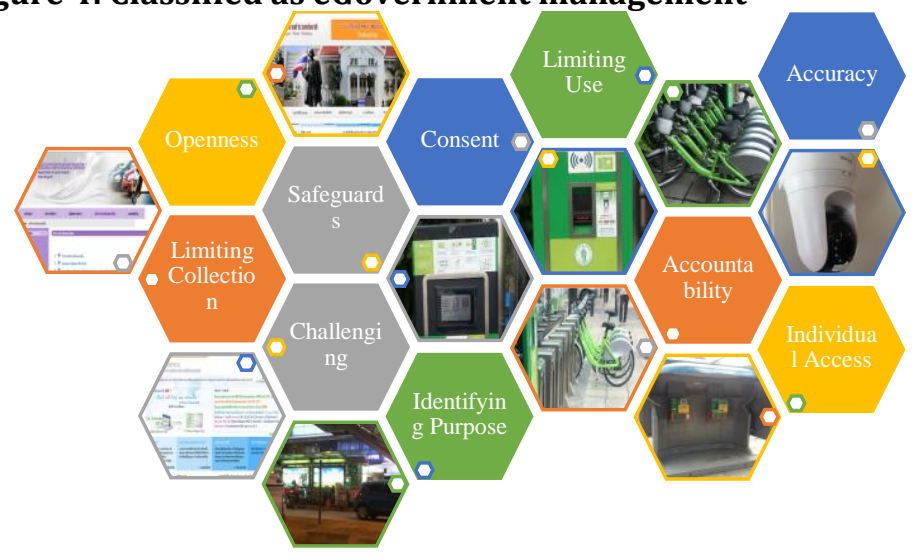

3. Methodology and Data Analysis

Methodology: In this research, the researcher used quantitative research methodology. Aim to study the issue of electronic government that could reduce the information gap between government and citizens. The questionnaire obtained information on the current status of electronic government in Thailand which intends to explain the factors that relating in information technology via 6 aspects. (see fig 5.) These 6 
aspects are 1) Investment 2) Officials' knowledge and understanding 3) Citizens' understanding 4) Networking 5) Promoting and 6) Policies by interviewing the state employees.

\section{Figure 5: Conceptual framework}

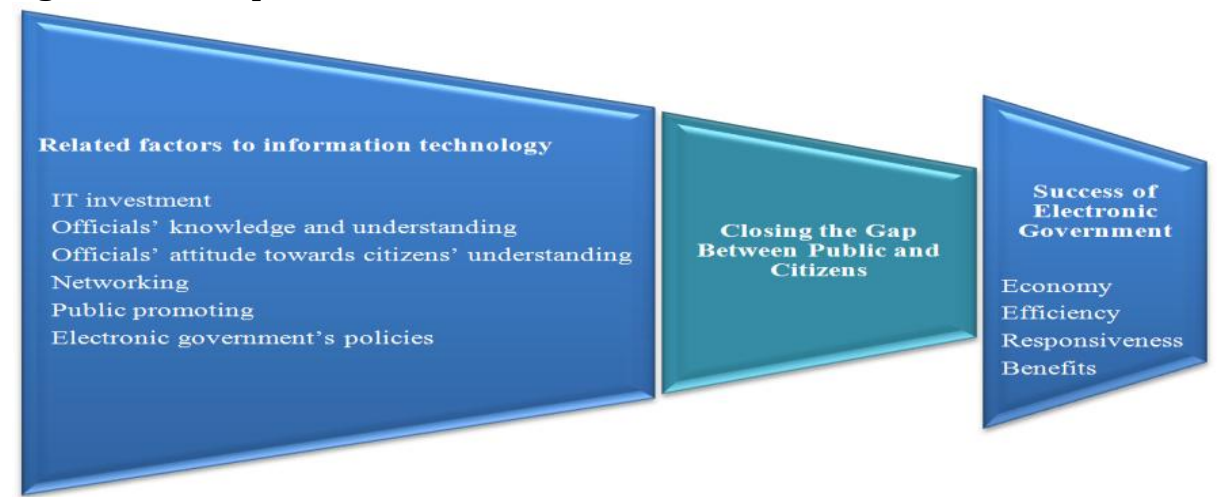

Data Collection: Data collecting from state employees in National Electronics and Computer Technology Center: NECTEC. NECTEC is responsible for cooperation in policy developing of technical services and transfer between the public and private sectors in more than 20 years (www.nectec.or.th), it is the central group of staffs with extensive knowledge of electronics and computer technology.

Reliability and Validly of Measures: The measurement was conducted using confirmatory factor analysis; all items have a loading $\geq 0.3$. Kaiser-Myer-Olkin (KMO) test has a value of 0.82 . Whereas the internal consistency reliability of measure was tested using Cronbach's alpha and all items have values $\geq$ 0.7 .

Data Analysis: The results were presented in explained content analysis in information technology via 6 aspects; 1) Investment 2) Officials' knowledge and understanding 3) Citizens' understanding 4) Networking 5) Promoting and 6) Policies.

\section{Results and Conclusion}

The results were analyzed from the questionnaire. It was found that the specifics are as follows:

Investment: In the 2013s fiscal year plans and budgeting, budget allocations for the integration of ICT in the public sector by considering the national strategic plan and the ASEAN community strategies, to increase the competitiveness of the country getting away from middle-income countries. By investing in infrastructure and logistics included the links and the ability to accommodate. Integrated development of ICT to promote modern standards of access and associated management of the database assessed. Ministry of Information and Communication technology is governed primarily to support the delivery of information and links to government agencies. There are some sub-coordinator major agencies helping in save and reduce the budget such as the Ministry of Interior, Ministry of Health, Ministry of Education and the Ministry of Finance. Nowadays many government agencies have performed the installation of IT network for use within their own organizations. The mission of limitation but there is no plan for any network to use the integration between government agencies. Therefore, the redundancy of the network infrastructure is a duplication of investment in hardware, people ware location for the installation of a computer system and implementation of a data contained capacity of computer equipment. In the consideration of the Ministry of Finance in IT network investment in various organizations of public sector across the country found that in 2013 mostly invested in networking and IT was more than 14,000 million baht of budget. ICT 2013 fiscal year aimed to integrate ICT in the public sector by investment in devices sharing between government agencies.

The Office of Electronic Government Agency: EGA (Public organization) has initiated the process of preparation of the communication network linking between government agencies, called GIN (Government Information Network) is a network in the transmission of information within the government both central and regional levels (Government Intranet). EGA has developed service sector share (Common Services) to integrate the data while reduce litigation spending over the network. GIN is the primary connection can reduce the redundancy in network installation service in each of the active application (Chengchao, 2013). For the year 2014, the budget for the development of communication 
technology is focusing on promoting public access to the internet in public and effectiveness of electronic government service. Include support and improve the competitiveness of industry and communications in software, hardware, electronic transactions and related industries. As well as develop and manage data and information in order to plan more effectively and efficiency.

Officials' knowledge and understanding: The data from each agency have a different system and format for storing, the segmentation of the data: primary data and secondary data. The data analysis system for the preparation of the information required to support the whole of the public sector to manage and analysis data from multiple departments and multiple formats. For efficiency of workforce planning, Office of The Civil Service Commission joined with EGA to develop the system for the public sector (Government Manpower Information System: GMIS) for use in the public sector workforce planning at the national level by collecting information from the central administration. Using information of manpower to provide advice and counsel to the cabinet on policy and strategic in human resource management sector. In the field of human resource management, the data used to determine remuneration policy, workforce planning and other aspects. According to officials with insight and practical guidance in the same way it always has held a workshop on the development of information systems for the public sector.

Present an overview and guiding the implementation of the project is the development of information technology sector gather opinions from various government agencies. The objective is to achieve the benefits, and government agencies to cooperate in the implementation of the project restructured more efficiently continue. Such concepts in the training like the development of information technology officers' project, overview of information systems officers' project, clarify the preparation of a memorandum of cooperation between agencies project, preparation and development of information technology officers' project, small group seminars and opinion survey. These projects were getting full cooperation from government agencies at all levels, including the Department of Local Government, Office of the Bangkok Metropolitan Administration Civil Service Commission, Bunditpatanasilpa Institute, Office of Teacher and education Personnel Commission, Office of the National Anti-Corruption Commission, Office of the Auditor General of Thailand, Office of the Higher Education Commission, Royal Thai Police, The Secretariat of the House of Representatives, The Administrative Court, Courts of Justice, The Constitutional Court, Office of the Attorney General, The Secretariat of the Senate and Office of the Election Commission, etc. (Electronic Government Agency, n.d.)

Citizens' understanding: In the view of the involvement of citizens in the electronic government of people acknowledges and participation. The public sectors accepted in people participation and development of a people-centered government services. Survey of the implementation of Thailand's electronic government conducted by UN, satisfactory results found that there is knowledge sharing of information through the website in term of e-Information. Hundred percent of announcement on policy implementation by the government, 89 percent of public official's readiness to communicate via electronic mail, 61 percent of building website of the government that people are exchanging conversations or comments through public discussion. (e-Consultation), 49 percent were creating survey and feedback online for citizens' complaint. 61 percent of government website created web board and chat room (e-Decision Making) by 45 percent of public office has providing an official to accept public complaint, and 90 percent of government website has online complaint system.

However, the key issue of Thailand is accessed to information and communication technologies problem. The Household Information and Communication Technology Survey in 2013 conducted by the Office for National Statistics show that 22.2 million shares from 63.3 million of total population using computer (35.0 percent), 18.3 million using internet (28.9 percent) and 46.4 million (73.3) mobile phones users, compared to the area of the municipality and outside the municipality the proportion of computer users was $46.3: 29.1$, internet users was $39.9: 23.1$ and mobile phone users holds $80.0: 69.8$. Consider the trend of computer, internet and mobile phone users from 2009 to 2013 found that computer users have increased from 29.3 percent (17.9 million shares) to 35.0 percent (22.2 million shares), internet users increases from 20.1 percent (12.3 million) to 28.9 percent (18.3 million), the use of mobile phones increased from 56.8 percent ( 34.8 million) to 73.3 (46.4 million); Although the user of ICT has steady increased. There are wide gaps between those used in municipal and non-municipal area. During the years $2009 \mathrm{~s}$ to $2013 \mathrm{~s}$, computer users in the municipality has increased from 42.0 percent to 46.3 percent while the users who are outside the municipality increased from 23.6 percent to 29.1 percent. Internet users in the municipality has increased from 32.8 percent to 39.9 percent while users outside the 
municipality increased from 14.5 percent to 23.2 percent, and the use of mobile phones within the municipality has increased from 68.9 percent to 80.0 percent, while outside municipalities increasing percent 51.5 percent to 69.8 . The proportion of ICT in the household between 2009s to 2013s, found that households with landline phones has decreased from 21.4 percent to 14.0 percent, in contrast households with fax up slightly from 1.5 percent to 1.7 percent and households with computers increased from 20.3 percent to 28.7 percent. The households with internet connections have increased from 9.5 percent to 23.5 percent they were connecting to the internet by fixed broadband and narrowband. Wireless mobile phone 2G, 2.5G (including GSM, CDMA, GPRS) with 17.0 percent and 16.5 percent of Broadband wireless mobile with 3G (WCDMA, EV-DO) and Analogue modem, ISDN, with only 8.7 percent. (Office of National Statistics, 2013)

Networking: Integration of ICT in the public sector was an investment financing, device sharing between government agencies. The Electronic Government Agency (EGA) has developed guidelines for preparation of the communication network linking government agencies, called GIN (Government Information Network) which is a network in information transmit within the central and local government (Government Intranet). It has undertaken the preparation of the cloud services sector as the host of large number of computers connected together to share resources and coprocessor. The host computer does not need to be in the same place it is well connected by a network of high-speed data communications. Through allocated of system resources both hardware and software applications to support the integration of information and reduce redundancy in the budget. In FY 2013, 123 million baht allocated to EGA in operating a public cloud service system. This will result in the integration of information within government agencies between central and regional levels (Government Intranet) and the communications link can be found through the internet. Network Design Concept of GIN is a network that links units within the public sector together with a government intranet linking. Form of networking through a collaborative network of TOT and CAT in the core layer, which makes the network redundancy and high availability that it will rare unavailable. The 4 equipment in the core layer are installed in different locations. The connection between GIN will provide VLAN / PVC for each of the 274 access node separated. The authorities have their own VLAN ID / PVC ID, also has VLAN / PVC access mode, each of it has its own network. No need to present in same location, and thus have the higher security.

The linked communication through the internet expected that the operation will have an integration of ICT in the public sector as an efficiency and effectiveness result included in an integrated network of government information, no limitation in intranet, internet and extranet. The budget is set as the original units that are already available. The Government Information network will be considered as will be no redundancy in the network and on complexity of budget processes. Agencies which their own network no need to replace to GIN, only open network for EGA to connect. In contrast the agency which does not have its own network should be used GIN, to reduce the cost and redundancy that would occur if each agency's request for budget approval to build their networks (Electronic Government Agency, n.d.)

Promoting: To enable the government to materialize its policy for the best benefits of the public, government and business sectors, the Electronic Government Agency (Public Organization) (EGA) was established according to the Cabinet resolution. The new agency is a government body under the Ministry of Information and Communication Technology and is under supervision of the Minister of Information and Communication Technology. Its main responsibility is to drive the implementation of electronic government activities, encourage the implementation of public online service and increase opportunities and equal access to the government services (Chengchao, 2013). National Electronics and Computer Technology Center: NECTEC, which cooperate between the private sectors and public sectors by supporting, coordinating and monitoring of the project. Develop the technology of the public sector, private sector and academic institutions to build ability and capability of electronics and computer technology. Using website to promote activities and disseminate knowledge about technology in electronics and computer project or training with emphasis on the key target, the youth launch in activities such as Thailand ICT Contest Festival, National Software Contest: NSC, Young Scientist Competition: YSC, NECTEC Electronics Camp: NECTEC eCamp, Youth's Electronics Circuit Contest: YECC, National Linux Competition: NLC and Expanding your Horizons: EYH. The event visiting by the operator, welcomed visitors and the public sector, private sector and educational sector is the best way to publicize the center. In the same time, rising a partnership between the centre and others in the future and make visitors feel that they get a treated well reception when contacted (National Electronics and Computer Technology Center, n.d.) 
Electronic government's policies: The government aims to develop standard of electronic government, and to provide consultancy and knowledge of electronic government services are divided into 5 areas: Network Services, Application Services, Information Security Services, System Integration and Technology Transfers by to divided into five phases. Phase 1 Inception Phase: study and analyze the feasibility and determine the initial agreed between stakeholders. Phase 2 Elaboration Phase: study and analyze the feasibility of design and details of the system. Phase 3 Planning Phase: planning and developing detail of technical, budget estimate, time estimate, risk analysis and risk management requirements. Phase 4 Construction Phase: construct of a system in practical network hardware and basic software applications. Phase 5 Adoption Phase: driving by create a new environment, processes and systems to work. The government has initiated the integration of public service channels with online services through mobile devices. Ministry of Information and Communication Technology, as well as government agencies involved allocate to the expansion of telecommunications infrastructure and communication channels. Include fully access to ICT, closing the gap of population cause of different area in the country. And has added free of charge Wi-Fi to the whole country, starting in the big cities and urban areas. However, the creation of information technology and communications must be stable and safe of citizens' is one of important factors to take into account of the electronic government project. (Institute for Information Technology Innovation, 2013)

\section{References}

Bannister, F. (2010). Deep E-Government: Beneath the Carapace, in E-Government Information, Technology, and Transformation, H. J. Scholl, Ed. Advance in management information systems, NY: M.E. Sharpe, 1, 36-38.

Chengchao, W. (2013). Integration of ICT policy and the allocation of government budget. IEEE Trans. IT. [Online]. pp. 1-8. Available: http://www.prd.go.th/ewt_dl_link.php?nid=56591\&filename=expert

Electronic Government Agency. (n.d.). EGA seminars brainstorm and develop the capacity of government officials. IEEE Trans. [Online]. Available: http://www.ega.or.th/Content.aspx?c_id=651

Electronic Government Agency. (n.d.). Government information network: GIN. IEEE Trans. [Online]. Available: http://www.ega.or.th/Content.aspx?m_id=62

Institute for Information Technology Innovation. (2013). Educational activities driven approach to e-government development in Thailand, Full Report, Dept. Eng., Kasetsart Univ., Bangkok, Thailand.

Isalam, M. S. \& Grönlund, Å. (2010). Agriculture Market Information Services (AMIS) in the Least Developed Countries (LDCs): Nature, Scopes, and Challenges," in Electronic Government, M. A. Wimmer, J.-L. Chappelet, M. Janssen and H. J. Scholl, Ed. Advance in $9^{\text {th }}$ IFIP WG 8.5 Conf., pp. 109-120.

Klischewski, R. (2010). Drift or Shift? Propositions for Changing Roles of Administrations in e-Government, in Electronic Government, M. A. Wimmer, J.-L. Chappelet, M. Janssen and H. J. Scholl, Ed. Advance in 9th IFIP WG 8.5 Conf., pp. 93.

Mohammad, N. (2008). Internal User' Self-Assessment of Malaysia's e-Government Flagship Applications in Lead Implementation Agencies. Ph.D. dissertation, Dept. Info. Sys., Isalamic Univ., Malaysia.

National Electronics and Computer Technology Center. (n.d.). Youth IT. IEEE Trans. [Online]. Available: http://www.nectec.or.th/index.php/2011-07-11-04-40-31/2011-05-12-07-55-01.html

Office of National Statistics. (2013). The household information and communication technology survey in 2013, Bangkok: Statistical Forecasting Bureau.

Ott, J. S., Hyde, A. C. \& Shafritz, J. M. (1990). Public management: The essential readings. Chicago: Lyceum Books/Nelson-Hall.

Rosenbloom, D. H. \& Kravchuk, R. S. (2005). Public administration: Understanding management, politics, and law in the public sector. NY: McGraw-Hill.

Yee, G., Khatib, K. E., Korba, L., Patrick, A. S., Song, R. \& Xu, Y. (2005). Privacy and Trust in E-Government, in Electronic Government Strategies and Implementations, W. Huang, K. Siau and K. K. Wei, Ed., PA: Idea Group, 7, 155-166. 